\title{
T-Lymphocyte Activation Antigen CD86
}

National Cancer Institute

\section{Source}

National Cancer Institute. T-Lymphocyte Activation Antigen CD86. NCI Thesaurus. Code C78147.

T-lymphocyte activation antigen CD86 (329 aa, 38 kDa) is encoded by the human CD86 gene. This protein plays a role in signal transduction that mediates T-cell proliferation and interleukin gene transcription. 